\title{
Korelasi antara Motivasi Belajar Siswa dalam Pembelajaran Online dengan Hasil Belajar Matematika di Masa Pandemi
}

\author{
Mohammad Nurwahid \\ Pascasarjana Pendidikan Matematika, Universitas Negeri Malang \\ J1.Semarang No.5, Sumbersari, Lowokwaru, Sumbersari, Kec. Lowokwaru, Kota Malang \\ Mohammadnurwahid96@gmail.com
}

\begin{abstract}
This research is motivated by the low learning motivation of students in online learning, this is in line with the low student learning outcomes as well. Therefore, the researcher wanted to find out whether there was a correlation between learning motivation and student mathematics learning outcomes in online learning during the pandemic. The research used is quantitative research with survey methods. Respondents of this study were 68 students of SMAN I Dukun. This research was conducted in November 2020. The instrument used to measure learning motivation was a questionnaire in the form of a google form, while the mathematics learning outcome data was obtained from the test results obtained from the mathematics teacher. After the data is tested for normality to find out whether the data is normally distributed or not. Because the data obtained were not normally distributed, to find out whether there was a correlation between learning motivation and learning outcomes, the Spearman's rho test was used. The results of the Spearman's rho test obtained a significance level of $0.950>0.05$, which means that there is no significant correlation between learning motivation and student mathematics learning outcomes. Meanwhile, the correlation coefficient is 0.008 , which means that the degree of correlation is very weak and the direction of the correlation is positive.
\end{abstract}

Keywords: correlation, learning motivation, mathematics learning outcomes, online learning

\begin{abstract}
Abstrak
Penelitian ini dilatarbelakangi rendahnya motivasi belajar siswa dalam pembelajaran daring hal ini selaras dengan hasil belajar siswa yang rendah juga. Olehkarena itu peneliti ingin mengetahui apakah ada korelasi antara motivasi belajar dengan hasil belajar matematika siswa dalam pembelajaran daring di masa pandemi. Penelitian yang digunakan adalah penelitian kuantitatif dengan metode survey. Responden penelitian ini adalah siswa SMAN I Dukun sebanyak 68 siswa. Penelitian ini dilaksanakan di bulan November tahun 2020. Instrumeen yang digunakan untuk mengukur motivasi belajar adalah kuesioner dalam bentuk google form, sedangkan data hasil belajar matematika diperoleh dari hasil ulangan yang diperoleh dari guru matematika. Selanjutnya data diuji normalitasnya untuk mengetahui apakah data tersebut berdistribusi normal atau tidak. Karena data yang diperoleh tidak berdistribusi normal maka untuk mengetahui apakah ada korelasi antara motivasi belajar dengan hasil belajar matematika digunakan uji spearman's rho. Hasil dari uji spearman's rho diperoleh taraf signifikansi 0,950 $>0,05$ yang artinya tidak ada korelasi yang signifikan antara motivasi belajar dengan hasil belajar matematika siswa. Sementara koefesien korelasinya diperoleh 0,008 yang artinya derajat korelasinya sangat lemah dan arah hubungannya positif.
\end{abstract}

Kata kunci: korelasi, motivasi belajar, hasil belajar matematika, pembelajaran online

Copyright (c) 2021 Mohammad Nurwahid

$\triangle$ Corresponding author: Mohammad Nurwahid

Email Address: Mohammadnurwahid96@gmail.com (J1.Semarang No.5, Sumbersari, Lowokwaru, Sumbersari)

Received 19 April 2021, Accepted 24 April 2021, Published 27 April 2021

\section{PENDAHULUAN}

Seperti yang banyak diberitakan di media masa bahwa di awal tahun 2020 hingga sekarang di Negara Indonesia bahkan di dunia dilanda wabah virus corona atau virus Covid-19. Seperti yang disampaikan oleh World Health Organization (WHO), Covid-19 adalah penyakit menular yang disebabkan oleh virus corona yang baru ditemukan. Sebagian besar orang yang terinfeksi virus Covid19 akan mengalami gangguan pernafasan ringan hingga sedang dan sembuh tanpa memerlukan perawatan khusus. Orang lanjut usia (lansia) yang berusia di atas 60 tahun dan yang memiliki penyakit 
bawaan seperti penyakit kardiovaskular, diabetes, penyakit pernafasan kronis, dan kanker, memiliki risiko lebih tinggi terkena penyakit yang parah hingga kematian. Cara terbaik untuk mencegah dan memperlambat penularan Covid-19 adalah memiliki pengetahuan yang cukup tentang penyakit tersebut dan cara penyebarannya. WHO menyarankan pada masyarakat untuk menjaga diri dan keluarga dari infeksi Covid-19 dengan cara rutin mencuci tangan, menggunakan pembersih tangan yang mengandung alkohol dan tidak menyentuh wajah. Covid-19 menjadi permasalahan tingkat dunia yang penyebarannya begitu menakutkan.

Dampak sebaran covid-19 ini, telah memaksa adanya kebijakan social distancing, atau dikenal dengan physical distancing (untuk menjaga jarak fisik), sebagai upaya untuk meminimalisir dan mencegah Covid-19. Secara umum, kebijakan itu dibuat sebagai upaya memperlambat laju sebaran virus Covid-19 (Kartini et al., 2020). Sehingga dengan adanya kebijakan tersebut seluruh aktivitas masyarakat yang dulu dilakukan di luar rumah dengan berkumpul dan berkelompok, kini harus diberhentikan sejenak dan diganti dengan beraktivitas di rumah masing-masing (Cahyani et al., 2020). Selain itu pemerintah juga mengeluarkan pengumuman mengenai larangan ke sekolah dan melakukan pembelajaran secara bagi proses pembelajaran di berbagai jenjang pendidikan. Sehingga mengharuskan pendidik menggunakan metode daring untuk melanjutkan proses pembelajaran. Peserta didik belajar dari rumah masing-masing menggnakan aplikasi tertentu (Umairah, 2020).

Pembelajaran jarak jauh atau dapat juga disebut sebagai pembelajaran dalam jaringan atau daring, saat ini hampir semua para pelaku pendidikan menjadikannya salah satu solusi pembelajaran dalam menghadapi situasi wabah Pandemi Covid-19. Menurut Warmi et al., (2020) Pembelajaran daring menjadi tren dengan alasan agar tidak terjadinya pengumpulan orang dalam satu ruangan. Melalui gugus tugas Covid-19 dan melalui kementerian pendidikan Indonesia menerapkan sistem pembelajaran daring dengan menggunakan akses internet untuk menyampaikan materi. Sedangkan menurut Rahmawati (2016) Istilah pembelajaran jarak jauh tersebut sudah lama digaungkan bahkan diterapkan di dunia pendidikan, dalam hal ini proses pembelajaran lebih banyak dilakukan secara terpisah di luar kelas. Secara terpisah disini berarti antara guru dan murid tidak berada dalam satu ruangan yang sama (tidak terjadi melakukan face to face) bahkan waktunyanya pun bisa berbeda. Interaksi pendidik dan peserta didik dilakukan secara langsung maupun tidak langsung, misal dengan melakukan chatting lewat koneksi internet (langsung) maupun dengan berkirim email untuk sekedar mengumpulkan tugas (tidak langsung). Menurut Menurut Wulansari \& Manoy (2020) Pembelajaran Jarak Jauh (e-learning) atau daring merupakan suatu pendekatan pembelajaran yang pada pelaksanaannya tidak bertatap muka langsung di kelas, sehingga semua proses pembelajaran akan berbeda dengan yang di sekolah.

Keadaan ini tentu saja memberikan dampak pada kualitas pembelajaran, siswa dan guru yang sebelumnya berinteraksi secara langsung dalam ruang kelas sekarang harus berinteraksi dalam ruang virtual yang terbatas. Guru dituntut memberikan pengajaran yang baik, menciptakan suasana yang kondusif untuk belajar dan secara kreatif dan inovatif menggunakan media belajar yang menarik agar siswa dapat memahami materi pembelajaran dan tujuan pembelajaran dapat tercapai (Cahyani et al., 
2020). Salah satu mata pelajaran yang terkena dampak penerapan pembelajaran daring adalah matematika.

Setiap siswa memiliki pandangan yang berbeda terhadap matematika. Pandangan ini ada yang menilai bahwa matematika adalah ilmu yang penting tetapi tidak sedikit menganggap bahwa matematika hanya berkaitan dengan angka saja. Beberapa hal yang mendasar bahwa mata pelajaran matematika menjadi momok yang ditakuti, tetapi demikian bahwa matematika menjadi mata pelajaran yang selalu ada dalam setiap tes baik tes masuk sekolah ataupun tes kerja. Hal ini didasari bahwa matematika merupakan kemampuan dasar yang harus dimiliki oleh setiap orang yang dikenal dengan basic competence (Lestari et al., 2018). Selain itu matematika memiliki peranan penting dalam mengembangkan potensi siswaMeskipun matematika dianggap oleh kebanyakan orang memiliki kesulitan yang tinggi akan tetapi semua orang harus tetap mempelajari matematika, karena matematika bisa menjadi sarana bagi kita untuk memecahkan masalah baik masalah matematika itu sendiri maupun masalah yang terjadi dalam kehidupan sehari-hari. Pentingnya matematika nyatanya belum disadari benar oleh sebagian siswa. Siswa masih menganggap matematika itu sulit dipelajari, hal tersebut berdampak pada hasil belajar siswa yang masih rendah. Sehingga dalam masa pandemi ini, mengajar matematika adalah tantangan yang cukup besar bagi guru matematika.

Meskipun pembelajaran saat ini dilaksanakan secara daring, tujuan pembelajaran harus tetap dicapai dan diperhatikan. Melalui pembelajaran, siswa diharapkan menjadi pribadi yang berkualitas baik dalam bidang ilmu pengetahuan, teknologi dan akhlak. Pencapaian tujuan belajar dapat dilihat dari hasil belajar siswa. Hasil belajar siswa merupakan hal penting dalam kegiatan pembelajaran (Yana \& Sari, 2021). Sedangkan menurut (Warti, 2018) hasil belajar merupakan perubahan tingkah laku dari yang tidak bisa menjadi bisa dari yang belum tahu menjadi tahu. Misalnya: siswa mampu menirukan beberapa kalimat, mengumpulkan perbendaharaan kata, menghafalkan lagu, menghitung dan mengerjakan soal-soal matematika dan perubahan nilai sikap menghargai. Faktor yang dapat mempengaruhi tingkat hasil belajar adalah faktor internal dan faktor eksternal. Faktor internal adalah faktor yang bersumber dari dalam diri peserta didik yang mempengaruhi kemampuan belajarnya. Faktor internal ini meliputi: motivasi belajar, ketekunan sikap, kebiasaan belajar, kecerdasaan, minat dan perhatian, serta kondisi fisik dan kesehatan. Faktor eksternal adalah faktor yang berasal dari luar diri peserta didik yang mempengaruhi hasil belajar di antaranya keluarga, sekolah, dan masyarakat. Salah satu faktor penting yang dapat mempengaruhi tingkat hasil belajar adalah motivasi belajar yang ada pada diri siswa (Rahmawati, 2016).

Hal yang terpenting yang harus tetap dijaga dalam situasi pandemi Covid-19 adalah motivasi belajar siswa. Ini menjadi permasalahan utama dikarenakan guru tidak bertatap muka secara langsung dengan siswa. motivasi merupakan aspek yang harus dimiliki oleh siswa agar mampu meningkatkan hasil belajarnya (Warmi et al., 2020). Motivasi merupakan dorongan yang timbul baik dari dalam maupun luar yang mengakibatkan siswa dapat belajar dengan baik. Seseorang yang memiliki motivasi belajar yang baik sejalan dengan keinginannya untuk mendapatkan prestasi belajar yang terbaik juga (Warmi 
et al., 2020). Esensi dari motivasi belajar adalah dorongan internal dan eksternal pada peserta didik yang sedang belajar untuk mengadakan perubahan perilkau. Motivasi belajar adalah proses yang memberi semangat belajar, arah dan kegigihan perilaku. Artinya, perilaku yang termotivasi adalah perilaku yang penuh energi terarah dan bertahan lama. Motivasi dapat diperoleh siswa dari berbagai arah antara lain dari orang tua, masyarakat, guru dan media, baik itu media cetak maupun media elektronik (Warti, 2018).

Motivasi dibutuhkan untuk memicu aktivitas kerja, semangat kerja, inspirasi dan dorongan kepada karyawan untuk bekerja lebih baik. Bagi karyawan, motivasi merupakan elemen yang sangat penting untuk pencapaian tujuan organisasi. Merupakan proses psikologis yang mencerminkan interaksi antara sikap, kebutuhan, persepsi dan keputusan yang terjadi pada diri seseorang. Secara psikologis motivasi muncul sebagai faktor dalam diri seseorang yang disebut faktor intrinsik dan faktor dari luar disebut faktor ekstrinsik (Bariroh, 2018). Menurut Lomu \& Widodo (2018) motivasi intrinsik adalah motivasi yang timbul dari dalam diri siswa dan biasanya tidak perlu di dorong oleh orang lain. Siswa yang memiliki motivasi intrinsik yang baik biasanya memiliki tekad yang baik pula dalam mendapatkan hasil belajar yang terbaik. Berbeda dengan motivasi ekstrinsik motivasi ini biasanya harus ada dorongan dari luar dan akan tercipta jika memiliki lingkungan yang baik. Maksudnya adalah siswa yang memiliki motivasi yang lingkungan belajar yang baik dapat belajar dengan baik karena siswa yang lain memiliki motivasi yang baik juga, apalagi di situasi serperti ini motivasi diperlukan agar setiap siswa mampu meningkatkan hasil belajarnya. Indikator motivasi belajar menurut B. Uno (2009) dapat diklasifikasikan sebagai berikut: adanya hasrat dan keinginan berhasil, adanya dorongan dan kebutuhan dalam belajar, adanya harapan dan cita-cita di masa depan, adanya penghargaan dalam belajar, adanya kegiatan yang menarik dalam belajar, serta adanya lingkungan belajar yang tertib sehingga memungkingkan peserta didik dapat belajar dengan baik.

Adanya motivasi belajar yang kuat membuat siswa belajar dengan tekun yang pada akhirnya terwujud dalam hasil belajar siswa tersebut. Oleh karena itulah motivasi belajar hendaknya diterapkan pada diri siswa agar dengan senang hati siswa akan mengikuti materi pelajaran yang diajarkan oleh guru di sekolah. Perlu diterapkan pada diri siswa bahwa dengan belajarlah akan mendapatkan pengetahuan yang baik, siswa akan mempunyai bekal menjalani kehidupannya dikemudian hari. Oleh karena itu pendidik diharapkan dapat meningkatkan motivasi belajar siswa sekalipun melaksankan pembelajarann jarak jauh supaya hasil belajar siswa juga meningkat. Hal ini sesuai dengan hasil penelitian yang dilakukan oleh (Jatmiko, 2015) yang menyatakan bahwa terdapat hubungan positif yang signifikan antara motivasi belajar siswa dengan hasil belajar matematika siswa kelas X SMK NU Pace. Sedangkan berdasarkan hasil penelitian yang dilakukan oleh (Bhoke, 2017) menyatakan bahwa tidak terdapat hubungan yang signifikan antara motivasi matematika dengan hasil belajar matematika. Ini berarti motivasi matematika tidak memberikan kontribusi yang bermakna terhadap hasil belajar matematika. Salah satu faktor yang mempengaruhi hasil belajar matematika adalah kecerdasan yang dimiliki oleh anak itu sendiri, sementara sisanya dipengaruhi oleh faktor lain. Hal ini menunjukkan bahwa motivasi 
matematika tidak memiliki hubungan dengan hasil belajar matematika. Berdasarkan uraian di atas, peneliti ingin mengetahui apakah ada korelasi antara motivasi belajar siswa dalam pembelajaran online dengan hasil belajar matematika di masa pandemi.

\section{METODE}

Penelitian ini adalah penelitian kuantitatif dengan metode penelitian korelasional. Penelitian korelasional ini berupaya untuk melihat apakah antara dua variabel atau lebih memiliki hubungan atau korelasional atau tidak. Bila ada hubungan, peneliti melihat seberapa besar kekuatan hubungan tersebut. Dengan melihat besarnya kekuatan variabel tersebut diharapkan hasil penelitiannya memiliki daya ramal yang kuat, karena semakin tinggi hubungan yang dapat diungkapkan semakin tinggi daya ramalnya terkait dengan hubungan variabel-variabel terrsebut (Arifin, 2012). Sedangka untuk pengumpulan datanya menggunakan metode survey dengan menyebar kuesioner dalam bentuk google form kepada siswa dan dokumentasi. Survey digunakan untuk mengumpulkan data motivasi belajar siswa sedangkan dokumentasi digunakan untuk mengumpulkan data hasil belajar siswa selama pembelajaran daraing. Subyek penelitian ini adalah siswa kelas XI dan XII SMAN 1 Dukun Gresik yang berjumlah 68 siswa. Penelitian ini dilaksanakan pada bulan November 2020.

Instrumen yang digunakan dalam penelitian ini menggunakan data survey dan data hasil belajar siswa selama pandemi. Nilai atau hasil belajar siswa diperoleh dari guru matematika yang mengajar di kelas tersebut. Adapun surveynya dalam bentuk kuisioner yang dibuat dalam google form agar mudah diakses oleh siswa. Survey yang dibuat bertujuan untuk mengungkap secara detail tentang motivasi siswa dalam pembelajaran daring selama masa Pandemik Covid-19, Adapun aspek yang diteliti dalam penelitian ini terkait dengan aspek yang dijelaskan oleh B. Uno (2009) yang menuliskan 8 indikator motivasi belajar, yaitu konsentrasi, rasa ingin tahu, semangat, kemandirian, kesiapan, antusias atau dorongan, pantang menyerah, dan percaya diri. adapun jenis surveynya menggunakan skala likert. Menurut Sugiono (2018) skala likert digunakan sebagai alat untuk mengukur sikap, pendapat, dan persepsi individu atau sekolompok orang terhadap fenomena sosial.

Dengan menggunakan skala likert, maka variabel yang akan diukur dijabarkan menjadi dimensi, dimensi dijabarkan menjadi sub variabel kemudian sub variabel dijabarkan lagi menjadi indikatorindikator yang dapat diukur. Akhirnya indikator-indikator yang terukur ini dapat dijadikan titik tolak untuk membuat instrumen yang berupa pertanyaan atau pernyataan yang perlu dijawab oleh responden. Setiap jawaban dihubungkan dengan bentuk pernyataan atau dukungan sikap yang diungkapkan dengan kata-kata sebagai berikut.

Tabel 1. Skala Likert

\begin{tabular}{|l|c|}
\hline \multicolumn{1}{|c|}{ Kriteria Penilaian } & Skala \\
\hline Sangat setuju & 5 \\
\hline Setuju & 4 \\
\hline Cukup/netral & 3 \\
\hline Tidak setuju & 2 \\
\hline Sangat tidak setuju & 1 \\
\hline
\end{tabular}


Sementara itu, teknik analisis data pada penelitian ini dilakukan dengan menghitung presentase dari hasil skor yang telah diperoleh, adapun rumus dalam menghitung presentasenya adalah sebagai berikut.

$$
\text { Indeks } \%=\frac{T \times P n}{Y} \times 100 \%
$$

Keterangan:

$\mathrm{T}=$ Total jumlah responden yang memilih

Pn $=$ Pilihan angka skala likert

$\mathrm{Y}=$ Skor ideal

Hasil presentase yang telah diperoleh dilakukan interpretasi skor berdasarkan tabel interval berikut ini.

Tabel 2. Kriteria Interpretasi skor

\begin{tabular}{|c|l|}
\hline Presentase & \multicolumn{1}{c|}{ Kriteria Penilaian } \\
\hline $0 \%-20 \%$ & Sangat lemah \\
\hline $21 \%-40 \%$ & lemah \\
\hline $41 \%-60 \%$ & Cukup/netral \\
\hline $61 \%-80 \%$ & Kuat \\
\hline $81 \%-100 \%$ & Sangat kuat \\
\hline
\end{tabular}

Sedangkan untuk data hasil belajar akan disajikan dalam bentuk tabel frekuensi dan untuk menentukan interval prediket nilai menggunakan rumus $I p=\frac{K K M \text { Maks-KKM kelas }}{3}$. Setelah data motivasi belajar dan hasil belajar matematika siswa diketahui, selanjutnya data tersebut akan dianalis. Adapaun teknik analisis data yang digunakan pada penelitian ini adalah pearson's product moment correlation jika data berdistribusi normal, jika data tidak berdistribusi normal maka menggunakan uji statistic Sepearmans'rho dan menggunakan program Statistical Packages for Social Science (SPSS) version 22 for Windows untuk menemukan hubungan antara motivasi belajar daring terhadap hasil belajar matematika siswa di masa pandemi yang sebelumnya telah dilakukan uji normalitas. Adapun kriteria kekuatan hubungan disajikan dalam tabel berikut:

Tabel 3. Derajat korelasi

\begin{tabular}{|l|l|}
\hline Korelas & Tingkat hubungan \\
\hline $0,00-0,25$ & Hubungan lemah \\
\hline $0,26-0,50$ & Hubungan sedang \\
\hline $0,51-0,75$ & Hubungan kuat \\
\hline $0,76-1,00$ & Hubungan sangat kuat \\
\hline
\end{tabular}

Hasil perhitungan di atas, menjadi dasar dalam menganalisis secara mendalam dan menyimpulkan bagaimana gambaran motivasi belajar dan hasil belajar siswa serta mengetahui bagaimana korelasi antara motivasi belajar daring dengan hasil belajar siswa matematika selama masa Pandemik Covid-19.

\section{HASIL DAN DISKUSI}

Hasil angket motivasi belajar siswa sebagai berikut. 
Tabel 4. Hasil Survey Motivasi siswa terhadap Pembelajaran Daring per Indikator

\begin{tabular}{|l|l|l|l|}
\hline Indikator & Aspek & Presentase & keterangan \\
\hline Konsentrasi & $\begin{array}{l}\text { Perhatian terhadap penyampain materi } \\
\text { yang disampaikan guru }\end{array}$ & $80.88 \%$ & kuat \\
\cline { 2 - 4 } & $\begin{array}{l}\text { Mendengarkan dengan baik setiap } \\
\text { penjelasan materi yang disampaikan }\end{array}$ & $81.47 \%$ & sangat kuat \\
\cline { 2 - 4 } & $\begin{array}{l}\text { Mencatat materi yang disampaikan pada } \\
\text { saat pembelajaran }\end{array}$ & $82.94 \%$ & sangat kuat \\
\cline { 2 - 4 } & $\begin{array}{l}\text { Mematuhi peraturan yang diberikan pada } \\
\text { saatpembelajaran berlangsung }\end{array}$ & $82.65 \%$ & sangat kuat \\
\hline Rasa ingin tahu & $\begin{array}{l}\text { Ketertarikan terhadap bahan dan materi } \\
\text { yang disampaikan }\end{array}$ & $71.47 \%$ & kuat \\
\cline { 2 - 4 } & $\begin{array}{l}\text { Mengajukan pertanyaan terhadap materi } \\
\text { yang diajarkan }\end{array}$ & $67.06 \%$ & kuat \\
\hline Semangat & $\begin{array}{l}\text { Semangat dalam menyampaikan ide dan } \\
\text { pendapat pada saat pembelajaran }\end{array}$ & $69.71 \%$ & kuat \\
\hline Kemandirian & $\begin{array}{l}\text { Mampu menjawab atau mengerjakan } \\
\text { dengan baik tugas-tugas yang diberikan }\end{array}$ & $74.12 \%$ & kuat \\
\hline Kesiapan & $\begin{array}{l}\text { Antusias dan siap dalam menjawab } \\
\text { ataumengerjakan tugas-tugas yang } \\
\text { diberikan }\end{array}$ & $74.41 \%$ & kuat \\
\hline Dorongan & $\begin{array}{l}\text { Mempunyai keinginan untuk mendapatkan } \\
\text { nilaiterbaik dari setiap tugas }\end{array}$ & $87.94 \%$ & sangat kuat \\
\hline Pantang menyerah & $\begin{array}{l}\text { Bersungguh-sungguh dalam dalam } \\
\text { mengerjakan tugas }\end{array}$ & $80.29 \%$ & kuat \\
\hline Percaya diri & Percaya diri dalam mengerjakan tugas & $76.47 \%$ & kuat \\
\cline { 2 - 4 } & $\begin{array}{l}\text { Percaya diri dengan skor yang akan saya } \\
\text { dapatkan }\end{array}$ & $77.94 \%$ & kuat \\
\hline
\end{tabular}

Tabel 5. Data Hasil Survey Motivasi siswa terhadap Pembelajaran Daring

\begin{tabular}{|c|c|c|}
\hline Presentase & Kriteria Penilaian & frekuensi \\
\hline $0 \%-20 \%$ & Sangat lemah & 0 \\
\hline $21 \%-40 \%$ & lemah & 0 \\
\hline $41 \%-60 \%$ & Cukup/netral & 5 \\
\hline $61 \%-80 \%$ & Kuat & 42 \\
\hline $81 \%-100 \%$ & Sangat kuat & 21 \\
\hline Total & & 68 \\
\hline
\end{tabular}

Berdasarkan data di atas, motivasi siswa terbagi menjadi tiga kriteria yaitu cukup, kuat, dan sangat kuat. Sedangkan hasil indikator motivasi siswa terbagi menjadi dua kriteria yaitu kuat dan sangat kuat. Sedangkan hasil belajar siswa adalah sebagai berikut

Tabel 6. Data Hasil Belajar Siswa dalam Pembelajaran Daring

\begin{tabular}{|c|c|c|}
\hline Interval Predikat & Predikat & Frekuensi \\
\hline $90-100$ & Sangat Baik & 17 \\
\hline $80-89$ & Baik & 49 \\
\hline $70-79$ & Cukup & 2 \\
\hline$<70$ & Kurang & 0 \\
\hline Total & & 68 \\
\hline
\end{tabular}


Data tersebut adalah data rata-rata nilai ulangan harian tiga bab selama pembelajaran daring. Dari data tersebut, hasil ulangan harian siswa terbagi menjadi tiga kategori yaitu cukup, baik, dan sangat baik. Selanjutnya data tersebut di uji apakah berdistribusi normal atau tidak. Adapan hasil uji normalitas data motivasi dan hasil belajar daring di masa pandemic adalah sebagai berikut

Tests of Normality

\begin{tabular}{|l|r|r|r|r|r|r|}
\hline & \multicolumn{3}{|c|}{ Kolmogorov-Smirnov $^{\text {a }}$} & \multicolumn{3}{c|}{ Shapiro-Wilk $^{*}$} \\
\cline { 2 - 7 } & Statistic & \multicolumn{1}{|c|}{$\mathrm{df}$} & \multicolumn{1}{c|}{ Sig. } & \multicolumn{1}{c|}{ Statistic } & \multicolumn{1}{c|}{$\mathrm{df}$} & Sig. \\
\hline MOTIVASI & .110 & 68 & .039 & .975 & 68 & .184 \\
HASIL BELAJAR & .172 & 68 & .000 & .886 & 68 & .000 \\
\hline
\end{tabular}

a. Lilliefors Significance Correction

Gambar 1. Hasil Uji Normalitas

Karena banyak responden adalah 68 maka uji normalitas yang digunakan adalah uji normalitas kolmogorov-smirnov. Berdasarkan data tersebut diperoleh taraf signifikansi untuk data motivasi belajar siswa adalah 0,039<0,05, oleh karena itu data hasil survey motivasi belajar siswa adalah tidak berdistribusi normal. Sedangkan untuk data hasil belajar siswa diperoleh taraf signifikansi 0,00<0,05 yang artinya data hasil belajar siswa juga tidak berdistribusi normal.

Karena data hasil survey motivasi belajar dan data hasil belajar siswa tidak berdistribusi normal, maka untuk menguji apakah ada hubungan dan bagaimana hubungan antara motivasi belajar dengan hasil belajar matematika siswa dalam pembelajaran daring digunakan uji statistic non-parametric correlation Sepearman's rho. Adapun hasil uji Sepearmans'rho adalah sebagai berikut

\begin{tabular}{|c|c|c|c|c|}
\hline \multicolumn{5}{|c|}{ Correlations } \\
\hline & & & MOTIVASI & $\begin{array}{c}\text { HASIL } \\
\text { BELANAR }\end{array}$ \\
\hline \multirow[t]{2}{*}{ Spearman's rho } & MOTIVASI & $\begin{array}{l}\text { Correlation Coefficient } \\
\text { Sig. (2-tailed) } \\
\text { N }\end{array}$ & $\begin{array}{r}1.000 \\
68\end{array}$ & $\begin{array}{r}.008 \\
.950 \\
68\end{array}$ \\
\hline & HASIL BELAJAR & $\begin{array}{l}\text { Correlation Coefficient } \\
\text { Sig. (2-tailed) } \\
N\end{array}$ & $\begin{array}{r}.008 \\
.950 \\
68\end{array}$ & $\begin{array}{r}1.000 \\
68\end{array}$ \\
\hline
\end{tabular}

Gambar 2. hasil uji spearman's rho

Dari hasil uji tersebut diperoleh taraf signifikansi 0,950 > 0,05 yang artinya tidak ada korelasi yang signifikan antara motivasi belajar dengan hasil belajar matematika siswa. Sementara koefesien korelasinya diperoleh 0,008 yang artinya derajat korelasinya lemah dan hubungan korelasinya adalah positif, artinya semakin tinggi motivasi belajarnya maka semakin tinngi pula hasil belajarnya. Dari data dan analisi data yang diperoleh, motivasi dan hasil belajar siswa SMAN I Dukun dalam pembelajaran daring ini tergolong tinggi. Akan tetapi motivasi belajar tersebut tidak berpengaruh secara signifikan terhadap hasil belajar siswa. 
Hasil penelitian tersebut sejalan dengan hasil penelitian (Julianti \& Hatiarsih, 2020) yang menunjukkan bahwa terdapat hubungan positif antara motivasi belajar dengan hasil belajar matematika. Motivasi belajar dapat memberikan kontribusi sebesar 33\% terhadap hasil belajar matematika, sisana 76\% dari faktor lain. Sedangikan hasil penelitian (Wulansari \& Manoy, 2020) menunjukkan bahwa tedapat pengaruh motivasi belajar terhadap prestasi belajar siswa selama study at home dengan nilai thitung sebesar 2,683 lebih besar dari nilai t-tabel 2,051. Siswa yang memiliki motvasi yang tinggi akan memiliki keinginan yang besar untuk melakukan aktivitas pembelajaran sehingga tingkat pemahamannya terhadap pembelajaran menjadi lebih baik. Sehingga dapat diartikan siswa yang memiliki motivasi belajar tinggi cenderung memiliki hasil belajar yang baik dan siswa yang memiliki motivasi belajar rendah cenderung memiliki hasil belajar yang rendah.

\section{KESIMPULAN}

Berdasarkan hasil penelitian ini dapat disimpulkan bahwa terdapat korelasi yang lemah antara motivasi belajar dengan hasil belajar matematika siswa dalam pembelajaran daring di masa pandemi. Ini menunjukkan bahwa motivasi belajar matematika tidak memberikan kontribusi yang bermakna terhadap hasil belajar matematika dalam pembelajaran daring. Salah satu faktor yang mempengaruhi hasil belajar matematika adalah kecerdasan yang dimiliki oleh anak itu sendiri, sementara sisanya dipengaruhi oleh faktor lainnya. Bahkan dalam pembelajaran daring guru tidak bisa mengontrol siswa secara penuh ketika mengerjakan soal ulangan harian. Dengan kemajuan teknologi siswa akan mudah mengakses jawaban atau cara menjawab soal di internet. Hal ini juga dapat mempengaruhi hasil belajar matematika siswa. Akan tetapi dari hasil penelitian tersebut diperoleh informasi bahwa terdapat hubungan yang positif antara motivasi dan hasil belajar siswa yang berarti semakin tinggi motivasi belajar siswa semakin tinggi pula hasil belajarnya.

\section{REFERENSI}

Arifin, zaenal. (2012). metodologi penelitian pendidikan filosofi, teori, dan aplikasinya. Lentera Cendikia.

B. Uno, H. (2009). Teori Motivasi dan Pengukurnnya Analisis di Bidang Pendidikan. Bumi Aksara.

Bariroh, S. (2018). The Influence of Parents' Involvement on Children with Special Needs' Motivation and Learning Achievement. International Education Studies, 11(4), 96. https://doi.org/10.5539/ies.v11n4p96

Bhoke, W. (2017). Hubungan antara Motivasi dengan Hasil Belajar Matematika pada Siswa SMP. Annual Proceeding STKIP Citra Bakti NTT, 2017(November), 236-242.

Cahyani, A., Listiana, I. D., \& Larasati, S. P. D. (2020). Motivasi Belajar Siswa SMA pada Pembelajaran Daring di Masa Pandemi Covid-19. IQ (Ilmu Al-Qur'an): Jurnal Pendidikan Islam, 3(01), 123- 
140. https://doi.org/10.37542/iq.v3i01.57

Jatmiko. (2015). Hubungan Motivasi Belajar dengan Hasil Belajar Matematika Siswa Kelas X SMK Nahdhatul Ulama Pace Nganjuk. Math Educator Nusantara, 01(02), 205-213.

Julianti, N., \& Hatiarsih, R. (2020). Hubungan antara Motivasi Belajar dan Hasil Belajar Matematika pada Materi Barisan dan Deret. 139-148.

Kartini, I. I., Rohaeti, E. E., \& Fatimah, S. (2020). Gambaran Motivasi Belajar Peserta Didik Saat Pandemi Covid 19. Fokus, 3(4), 140-150.

Lestari, W., Pratama, L. D., \& Jailani, J. (2018). Implementasi Pendekatan Saintifik Setting Kooperatif Tipe STAD Terhadap Motivasi Belajar Dan Prestasi Belajar Matematika. AKSIOMA : Jurnal Matematika Dan Pendidikan Matematika, 9(1), 29. https://doi.org/10.26877/aks.v9i1.2332

Lomu, L., \& Widodo, S. A. (2018). Pengaruh motivasi belajar dan disiplin belajar terhadap prestasi belajar matematika siswa. Prosiding Seminar Nasional Pendidikan Matematika Etnomatnesia, $O(0), 745-751$.

Rahmawati, I. (2016). Pelatihan dan pengembangan pendidikan jarak jauh berbasis digital class platform edmodo. Prosiding Temu Ilmiah Guru (TING) VII, November, 593-607. https://onesearch.id/Record/IOS4882.6536

Sugiono. (2018). Metode Penelitian Kuantittif, Kualitatif, dan R\&D. CV. Alfabeta.

Umairah, P. (2020). Peningkatan Motivasi Belajar Menggunakan “ Google Classroom " Ditengah Pandemi Covid-19 Pada Peserta Didik Kelas Xi Ips 4 Sman 1 Bangkinang Kota. Journal On Education, 02(03), 275-285. http://www.jonedu.org/index.php/joe/article/view/319/250

Warmi, A., Adirakasiwi, A. G., Santoso, E., Karawang, U. S., Majalengka, U., Siswa, K. B., \& Daring, P. (2020). Motivasi dan kemandirian belajar siswa pada mata pelajaran matematika di masa pandemi covid-19 (Studi pada siswa kelas VII SMPN 3 Karawang tahun pelajaran 2019-2020). 8(3), 197-202.

Warti, E. (2018). Pengaruh Motivasi Belajar Siswa terhadap Hasil Belajar Matematika Siswa di SD Angkasa 10 Halim Perdana Kusuma Jakarta Timur. Mosharafa: Jurnal Pendidikan Matematika, 5(2), 177-185. https://doi.org/10.31980/mosharafa.v5i2.273

Wulansari, N. H., \& Manoy, J. T. (2020). Pengaruh Motivasi dan Minat Belajar Siswa Terhadap Prestasi Belajar Matematika Selama Study at Home. Jurnal Penelitian Pendidikan Matematika Dan Sains, 4(2), 72-81. http://journal.unesa.ac.id/index.php/jppms/ 
Korelasi anatara Motivasi Belajar Siswa dalam Pembelajaran Online dengan Hasil Belajar Matematika Di Masa Pandemi, Mohammad Nurwahid

Yana, Y., \& Sari, D. P. (2021). Investigasi Minat Dan Motivasi Belajar Matematika Siswa Di Era Covid19. Statmat : Jurnal Statistika Dan Matematika, 3(1), 19. https://doi.org/10.32493/sm.v3i1.8184 